\title{
Papillary Intralymphatic Angioendothelioma
}

National Cancer Institute

\section{Source}

National Cancer Institute. Papillary Intralymphatic Angioendothelioma. NCI Thesaurus. Code C7526.

An intermediate, rarely metastasizing blood vessel neoplasm. It is characterized by the presence of lymphatic-like vascular channels and papillary endothelial proliferation. 